\title{
Lipokalina związana z żelatynazą neutrofilów jako marker ostrego uszkodzenia nerek u chorych onkologicznych leczonych cisplatyną
}

\author{
Dawid Szumilas ${ }^{1}$, Jerzy Wojnar ${ }^{1}$, Jerzy Chudek ${ }^{1,2}$
}

Cisplatyna jest powszechnie stosowanym chemioterapeutykiem w terapii nowotworów litych. Jej głównym działaniem niepożądanym, ograniczającym możliwość stosowania większych dawek, jest nefrotoksyczność, prowadząca do ostrego uszkodzenia nerek (Acute Kidney Injury - AKI). W celu monitorowania funkcji nerek oraz wykrycia AKI w trakcie terapii cisplatyną wykonuje się seryjne oznaczenia kreatyniny w surowicy, na podstawie których jest wyznaczana wielkość filtracji kłębuszkowej. Metoda ta pozwala na wykrycie AKI z 24-48-godzinnym opóźnieniem, przy znacznym zmniejszeniu filtracji kłębuszkowej. Prowadzone w ostatnich latach badania wyłoniły grupę potencjalnych tak zwanych morfologicznych markerów, które pozwalają na wcześniejsze wykrycie uszkodzenia nerek, również przebiegającego subklinicznie (bez istotnego wzrostu stężenia kreatyniny w surowicy), po zabiegach kardiochirurgicznych i po podaniu środków cieniujących. Najlepiej poznanym z tych markerów jest lipokalina związana z żelatynazą neutrofilów (neutrophile gelatinase asociated lipocalin — NGAL). Jest to białko, które w warunkach fizjologicznych występuje w ziarnistościach neutrofilów, szpiku kostnym, płucach, żołądku, jelicie cienkim i grubym, trzustce oraz nerkach, a w przebiegu uszkodzenia nabłonka cewki nerkowej dochodzi do wzrostu jego ekspresji. Przeprowadzone badania wykazały użyteczność oznaczeń NGAL zarówno w surowicy, jak i w moczu w diagnostyce wczesnego uszkodzenia nerek o etiologii niedokrwiennej. Dotychczas przeprowadzone badania wśród chorych onkologicznych leczonych cisplatyną nie potwierdziły użyteczności oznaczeń NGAL w surowicy, natomiast oznaczenia w moczu pozwalały wykryć AKI znacznie wcześniej niż standardowe oznaczenia kreatyniny w surowicy. Niniejsza praca stanowi przegląd systematyczny tych badań.

\section{Neutrophil gelatinase-associated lipocalin as a marker of acute renal failure in cancer patients treated with cisplatin}

Cisplatin is a widely used chemotherapeutic agent in the treatment of solid tumours. Its main side effect, limiting the use of higher doses, is nephrotoxicity manifested by acute kidney injury (AKI). Monitoring of kidney function and AKI detection during the treatment with cisplatin requires a serial measurements of serum creatinine, with estimation of glomerular filtration rate. This method allows the detection of AKI with a 24-48 hour delay, when glomerular filtration rate is significantly decreased. Research conducted in recent years has indicated a group of potential so-called morphological markers of kidney damage that allow earlier detection of AKI, also with subclinical manifestation (without a significant increase in serum creatinine). This is following cardiac surgery and after administration of contrast agents. The best characterised of these markers is neutrophil gelatinase-associated lipocalin (NGAL). It is a protein physiologically existing in the granules of neutrophils, bone marrow, lung, stomach, small and large intestines, pancreas and kidney. Its expression increases in the course of renal epithelial damage. Studies have demonstrated the utility of NGAL assessed in both serum and urine in the diagnosis of ischemic AKI. So far, studies of cancer patients treated with cisplatin did not confirm the usefulness of NGAL determination in serum, but demonstrated that

\footnotetext{
${ }^{1}$ Katedra i Klinika Chorób Wewnętrznych i Chemioterapii Onkologicznej

${ }^{2}$ Zakład Patofizjologii Katedry Patofizjologii
}

Wydział Lekarski

Śląski Uniwersytet Medyczny w Katowicach 
its urine measurements enable earlier diagnosis of AKI than the routine serum creatinine assessment. This paper is a systematic review of these studies.

NOWOTWORY J Oncol 2016; 66, 2: 160-166

Słowa kluczowe: ostre uszkodzenie nerek, cisplatyna, nefrotoksyczność cisplatyny, lipokalina związana z żelatynazą neutrofilów, wczesne wykrywanie uszkodzenia nerek

Key words: acute kidney injury, cisplatin, nephrotoxicity, neutrophil gelatinase-associated lipocalin, early diagnosis of kidney injury

\section{Wstęp}

Cisplatyna jest powszechnie stosowanym chemioterapeutykiem wykorzystywanym w terapii nowotworów litych. Stosowanie tego leku wiąże się z występowaniem wielu działań niepożądanych, takich jak ototoksyczność, neurotoksyczność, mielotoksyczność, nefrotoksyczność oraz nudności i wymioty [1]. Na szczególną uwagę zasługuje nefrotoksyczność, która została opisywana już na etapie badań przedklinicznych, a później potwierdzona w badaniach klinicznych z cisplatyną [2, 3]. Jest to główny czynnik ograniczający możliwość stosowania większych dawek cisplatyny w praktyce klinicznej. Aby zmniejszyć częstość wystąpienia ostrego uszkodzenia nerek (Acute Kidney Injury - AKI), przed podaniem cisplatyny stosowane jest intensywne nawadnianie [4]. Jednak pomimo to AKI nadal dotyka około $20 \%-30 \%$ pacjentów leczonych tym chemioterapeutykiem [5, 6]. Wystąpienie AKI powoduje konieczność zmniejszenia dawki lub przerwania stosowania cisplatyny, co z kolei ogranicza skuteczność leczenia i stanowi niezależny czynnik pogarszający rokowanie wśród pacjentów onkologicznych [7, 8].
Ponadto czynność nerek u części pacjentów z AKI zostaje trwale upośledzona [9].

Metodą służącą do rozpoznawania AKI jest ocena przesączania kłębuszkowego (Glomerular Filtration Rate - GFR), poziomu kreatyniny lub diurezy zgodnie z kryteriami RIFLE (tab. I) bądź ich modyfikacją AKIN (tab. II) [10, 11]. Przesączanie kłębuszkowe może zostać wyliczone na podstawie pomiarów stężenia endogennego markera w surowicy oraz w godzinowej/dobowej zbiórce moczu. Idealny marker przesączania kłębuszkowego powinien mieć kilka cech: być swobodnie przesączanym w kłębuszkach nerkowych, nie ulegać wydzielaniu lub zwrotnemu wchłanianiu w cewkach nerkowych oraz nie być metabolizowanym pozanerkowo. Endogennym markerem, który w największym stopniu spełnia wyżej wymienione wymagania, jest kreatynina. Jednak prowadzenie godzinowej zbiórki moczu praktycznie wymaga cewnikowania pęcherza moczowego, narażając chorego na zakażenie układu moczowego, jest uciążliwe i nie powinno być stosowane tylko z tego powodu. Zaś dobowa zbiórka u osoby niezacewnikowanej jest zwykle niekompletna, co

Tabela I. Podział ostrego uszkodzenia wg klasyfikacji RIFLE (Risk of renal dysfunction, Injury to the kidney, Failure of kidney function, Loss of kidney function, End-stage kidney disease - Ryzyko, Uszkodzenie, Niewydolność, Utrata funkcji, Schyłkowa choroba nerek). Pierwsze trzy kategorie określają stadia ciężkości ostrej niewydolności nerek, natomiast ostatnie dwie to kategorie rokownicze odnoszące się do sytuacji, w której ostre uszkodzenie nerek przechodzi w przewlekłe [10]

\begin{tabular}{|c|c|c|}
\hline Kategoria & Kryterium kreatyniny/GFR & Kryterium diurezy \\
\hline \multicolumn{3}{|l|}{ Kategorie ciężkości } \\
\hline Ryzyko (Risk) & $\begin{array}{l}\text { 1,5-krotny wzrost kreatyniny } \\
\text { lub obniżenie GFR o }>25 \%\end{array}$ & $<0,5 \mathrm{ml} / \mathrm{kg} / \mathrm{h}$ przez $6 \mathrm{~h}$ \\
\hline Uszkodzenie (Injury) & $\begin{array}{l}\text { 2-krotny wzrost kreatyniny } \\
\text { lub obniżenie GFR o }>50 \%\end{array}$ & $<0,5 \mathrm{ml} / \mathrm{kg} / \mathrm{h}$ przez $12 \mathrm{~h}$ \\
\hline Niewydolność (Faliure) & $\begin{array}{c}\text { 3-krotny wzrost kreatyniny } \\
\text { lub obniżenie GFR o }>75 \% \\
\text { lub kreatyninemia }>4 \mathrm{mg} / \mathrm{dl}, \text { gdy nastąpił } \\
\text { gwałtowny wzrost } \\
00,5 \mathrm{mg} / \mathrm{dl}\end{array}$ & $\begin{array}{l}<0,3 \mathrm{ml} / \mathrm{kg} / \mathrm{h} \text { przez } 24 \mathrm{~h} \\
\text { lub bezmocz przez } 12 \mathrm{~h}\end{array}$ \\
\hline \multicolumn{3}{|l|}{ Kategorie rokownicze } \\
\hline Utrata funkcji (Loss) & \multicolumn{2}{|c|}{$\begin{array}{l}\text { Przetrwała ostra niewydolność nerek — całkowita utrata czynności nerek } \\
\text { utrzymująca się > } 4 \text { tygodni }\end{array}$} \\
\hline Schyłkowa choroba nerek (End) & \multicolumn{2}{|c|}{ Schyłkowa niewydolność nerek utrzymująca się > 3 miesięcy } \\
\hline
\end{tabular}


Tabela II. Podział ostrego uszkodzenia nerek wg kryteriów AKIN (Acute Kidney Injury Network), które stanowi modyfikację kryteriów RIFLE [11]

\begin{tabular}{lcc}
\hline Stopień & Kryterium kreatyniny & Kryterium diurezy \\
\hline 1 & $\begin{array}{r}1,5-2 \text {-krotny wzrost kreatyniny } \\
\text { lub wzrost } \geq 0,3 \mathrm{mg} / \mathrm{dl}\end{array}$ & $<0,5 \mathrm{ml} / \mathrm{kg} / \mathrm{h} \mathrm{przez} 6 \mathrm{~h}$ \\
& $2-3$-krotny wzrost kreatyniny & $<0,5 \mathrm{ml} / \mathrm{kg} / \mathrm{h} \mathrm{przez} 12 \mathrm{~h}$ \\
3 & $>3$-krotny wzrost kreatyniny lub kreatyninemia $>4 \mathrm{mg} / \mathrm{dl}$, & $<0,3 \mathrm{ml} / \mathrm{kg} / \mathrm{h} \mathrm{przez} \mathrm{24} \mathrm{h} \mathrm{lub} \mathrm{bezmocz} \mathrm{przez} 12 \mathrm{~h}$ \\
& gdy nastąpił gwaltowny wzrost o $0,5 \mathrm{mg} / \mathrm{dl}$ & \\
\hline
\end{tabular}

ogranicza dokładność i tym samym przydatność metody obliczenia filtracji kłębuszkowej. Dlatego w praktyce klinicznej wartość przesączania kłębuszkowego jest wyliczana pośrednio za pomocą wzoru MDRD, na podstawie takich parametrów jak poziom kreatyniny w surowicy, płeć, wiek, masa ciała oraz rasa - jest to szacowany współczynnik przesączania kłębuszkowego - eGFR (estimated Glomerular Filtration Rate) [12]. Stosowanie wzoru Cockcrofta-Gaulta nie jest już rekomendowane przez KDIGO (Kidney Disease Improving Global Outcomes), a użycie najnowszego wzoru CKD-EPI wymaga wykonania oznaczenia stężenia kreatyniny metodami kalibrowanymi IDMS (Isotope Dilution Mass Spectrometry), które są rzadko dostępne.

Kreatynina, pomimo że jest powszechnie stosowana do oceny przesączania kłębuszkowego, ma kilka cech, które ograniczają jej przydatność w ocenie AKI. Substancja ta ulega swobodnej filtracji kłębuszkowej, jednak jest również wydzielana w cewkach nerkowych w ilości wynoszącej 10\%$-40 \%$ [13]. Stężenie kreatyniny w surowicy jest pochodną kilku czynników, zależy między innymi od masy mięśniowej, wieku, płci, oraz diety (spożycie mięsa). Ponadto wzrost stężenia kreatyniny występuje z pewnym opóźnieniem wstosunku do zmniejszenia filtracji kłębuszkowej, sięgającym nawet 48 godzin od zadziałania czynnika uszkadzającego. Również szacowanie filtracji kłębuszkowej, opierające się na wyżej wymienionych wzorach, jest obarczone analogicznym opóźnieniem.

Opisane powyżej ograniczenia sprawiają, że uszkodzenie nerek w takcie terapii cisplatyną jest wykrywane zopóźnieniem oraz dopiero w momencie, kiedy jest ono już znacznie zaawansowane, tym bardziej, że pierwotny mechanizm uszkodzenia nerek jest związany z uszkodzeniem nabłonka cewek nerkowych bliższych [14]. Możliwość diagnozowania subklinicznego uszkodzenia nerek, przebiegającego bez wzrostu kreatyninemii, pozwoliłaby na intensyfikację metod profilaktyki w kolejnych cyklach lub modyfikacji schematu leczenia. To z kolei prowadziłoby do zmniejszenia częstości występowania, a przede wszystkim ciężkości AKI, wpływając korzystnie na możliwość kontynuacji chemioterapii i ostatecznie na rokowanie pacjentów onkologicznych.

Obecnie prowadzone są intensywne poszukiwania nowych markerów, które mogłyby zastąpić oznaczenie kreatyninemii w diagnostyce AKI. Wśród kandydatów znajduje się białko uszkodzenia nerek 1 (Kidney Injury Molecule 1
- KIM-1), wątrobowy typ białka wiążącego kwasy tłuszCzowe (Liver-Fatty Acid Binding Protein — L-FABP), interleukina 18, oraz - najlepiej poznana — lipokalina, związana z żelatynazą neutrofilów (Neutrophil Gelatinase Associated Lipokalin - NGAL) [15-17].

\section{NGAL}

NGAL, zwany również lipokaliną 2 lub siderokaliną, jest białkiem o masie 25-kDa, które zostało pierwotnie wykryte w ziarnistościach neutrofili. Uwolnione z komórek, ogranicza rozwój mikroorganizmów dzięki właściwościom wiązania się z sideroforami - wytwarzanymi przez bakterie związkami helatującymi żelazo, które jest wykorzystywane do ich wzrostu [18]. Poza tą bakteriostatyczną rolą NGAL pełni w organizmie szereg innych ważnych funkcji, między innymi uczestniczy w procesach różnicowania komórek nabłonkowych nerki [19]. W dojrzałym organizmie, w warunkach fizjologicznych, ekspresję tego białka zachowują komórki szpiku kostnego, tchawicy, płuc, żołądka, jelita cienkiego i grubego, trzustki oraz nerek [17, 20].

NGAL występuje pod kilkoma postaciami, między innymi jako monomer o masie $25-\mathrm{kDa}$, homodimer o masie 46-kDa oraz heterodimer o masie 135-kDa, który jest związany z metaloproteinazą macierzy zewnątrzkomórkowej 9 (Matrix Metalloproteinase type 9-MMP-9) [21]. Przyjmując jako punkt odcięcia masę 100-kDa, można podzielić postaci NGAL na dwie frakcje: o niskim ciężarze cząsteczkowym (Low Mollecular Weight - LMW) oraz o wysokim ciężarze cząsteczkowym (High Mollecular Weight - HMW). W surowicy 82\% puli krążącego NGAL stanowi forma HWM, natomiast w moczu 99\% to forma LMW [22]. Z krążenia NGAL jest usuwany przez nerki drogą filtracji kłębuszkowej i w zależności od wielkości cząsteczki biologiczny czas półtrwania (T1/2) w krążeniu wynosi od 10 minut (dla monomeru) do 20 minut (dla dimeru) [23]. Z moczu pierwotnego znaczna część NGAL jest reabsorbowana przez komórki cewek proksymalnych wmechanizmiezależnymod megalinyikubuliny [18].Pozostała, niewielka ilość ulega wydaleniu z moczem ostatecznym.

W przypadku wystąpienia AKI w przebiegu niedokrwienia w nerkach dochodzi do zwiększenia syntezy mRNA kodującego NGAL, którego źródłem są głównie komórki ramienia wstępującego pętli Hellego oraz kanalików zbiorczych $[24,25]$. Tam zsyntetyzowane białko uwalniane jest do moczu, gdzie jego zwiększone stężenie ma prawdopodob- 
nie chronić organizm przed infekcją bakteryjną. W przebiegu AKI niewielka ilość NGAL wytwarzanego w nerce dostaje się do układu krążenia, powodując wzrost jego stężenia [18]. W przebiegu niedokrwiennego AKI dochodzi również do uszkodzenia innych narządów, zwłaszcza płuc, przebiegającego z nasileniem ekspresji NGAL [26]. Ta zwiększona ilość NGAL pojawiająca się w krążeniu ulega filtracji kłębuszkowej i pojawia się również w moczu pierwotnym, a uszkodzony nabłonek cewki bliższej zwiększa endocytozę NGAL [19, 24]. Hipotetycznie NGAL ma chronić komórki cewki bliższej przed dalszym uszkodzeniem oraz pobudzać reepitelializację. W badaniu eksperymentalnym przeprowadzonym na myszach z AKI wywołanym niedokrwieniem wykazano, że podanie egzogennego NGAL w 15 minut przed zadziałaniem czynnika uszkadzającego cewki, a nawet godzinę po, przeciwdziałało lub zmniejszało wzrost stężenia w surowicy kreatyniny, a w badaniu histopatologicznym ograniczało zmiany nekrotyczne w cewkach [19]. To protekcyjne działanie było uwarunkowane dokomórkowym transportem żelaza za pośrednictwem NGAL. Użyty w tym badaniu NGAL, pozyskany na drodze inżynierii genetycznej ze szczepu XL-1 Blue E. coli, był związany z enterocheliną (rodzajem sideroforu) oraz z żelazem. Natomiast zastosowanie NGAL produkowanego przez szczep BL21, niezwiązanego z sideroforem iżelazem, skutkowało ograniczonym efektem protekcyjnym. Istnieją wątpliwości, czy interakcje obserwowane w warunkach laboratoryjnych zachodzą również in vivo, ponieważ syderofory nie są syntetyzowane w komórkach ssaków. Wykazano jednak, że NGAL może się łączyć z katecholami - endogennymi związkami powstającymi na drodze metabolizmu między innymi aromatycznych aminokwasów i za ich pośrednictwem transportować żelazo [27].

Badania kliniczne przeprowadzone z udziałem chorych leczonych kardiochirurgicznie pokazały, że NGAL może być użytecznym, wczesnym markerem uszkodzenia nerek. W przypadku pacjentów pediatrycznych rozpoznanie AKI na podstawie wzrostu kreatyniny było możliwe po 24-72 godzinach po operacji kardiochirurgicznej [28], natomiast wzrost stężenia NGAL w moczu i surowicy był obserwowany już w drugiej godzinie po zabiegu powikłanym hipoperfuzją nerek, a pola pod krzywymi ROC dla tego przedziału czasowego wynosiły odpowiednio 0,906 oraz 0,998 . Również po zabiegach kardiochirurgicznych u osób dorosłych wykazano znaczną przewagę czasową w wykrywaniu AKI przy wykonywaniu pomiarów NGAL w porównaniu do kreatyniny [29]. Pole pod krzywą ROC dla oznaczenia NGAL w drugiej godzinie po zabiegu w surowicy oraz w moczu wyniosło odpowiednio $0,85 \mathrm{i}$ 0,96. W obu tych badaniach stwierdzono wyższą wartość diagnostyczną oznaczenia NGAL w moczu niż w surowicy.

Haase i wsp. dokonali analizy danych zebranych w 10 badaniach prowadzonych nad NGAL-em jako markerem AKI, wysuwając hipotezę, że wzrost stężenia NGAL bez wzrostu kreatyninemii identyfikuje pacjentów z tzw. subklinicznym uszkodzeniem nerek. Wykrycie tego subklinicznego AKI wiązało się z większą śmiertelnością oraz dłuższym czasem hospitalizacji [30]. Analiza objęła łącznie 2322 pacjentów kardiochirurgicznych bądź przebywających na oddziałach intensywnej terapii. Zostali oni podzieleni na 4 grupy w zależności od stężenia NGAL (oznaczonego bezpośrednio po przyjęciu na oddział, po wystąpieniu epizodu uszkadzającego nerki lub 24-48 godzin przed rozpoznaniem AKI) przewidującego wystąpienie AKI oraz od wzrostu kreatyninemii w surowicy, definiującego AKI zgodnie z kryteriami RIFLE: NGAL(-)/CREA(-), NGAL(+)/CREA(-), NGAL(-)/CREA(+), NGAL(+)/CREA(+). Pacjenci ze stwierdzonym wzrostem stężenia NGAL, ale bez wzrostu kreatyninemii, pozwalającej na rozpoznanie $A K I$, częściej w późniejszej obserwacji wymagali leczenia nerkozastępczego oraz mieli gorsze rokowanie niż pacjenci bez wzrostu NGAL oraz bez rozpoznanego AKI.

\section{NGAL w AKI wywołanym stosowaniem cisplatyny na modelach zwierzęcych}

Dane dotyczące AKI indukowanego podaniem cisplatyny, uzyskane w doświadczeniach na modelach zwierzęcych, wskazują, że wzrost stężenia NGAL w moczu pozwala na wykrycie uszkodzenia nerek znacznie wcześniej niż wzrost kreatyniny w surowicy krwi. W zależności od wielkości jednorazowo podanej dawki cisplatyny $(5,5-20 \mathrm{mg} / \mathrm{kg}$ masy ciała) oraz modelu zwierzęcego początek wzrostu NGAL w moczu był obserwowany w przedziale od 3 do 48 godzin, natomiast początek wzrostu kreatyniny w surowicy dopiero po 72-96 godzinach [31-33]. Zmiany w obrazie histopatologicznym pojawiały się już w 12 godzin po podaniu cisplatyny i cechowały się utratą rąbka szczoteczkowego na powierzchni komórek cewek bliższych, a po kolejnych 12 godzinach dochodziło do zmian nekrotycznych w samych komórkach [32]. Natomiast już w trzeciej godzinie po podaniu cisplatyny dochodziło do zwiększonego gromadzenia NGAL na drodze endocytozy w komórkach nabłonka cewek bliższych [31]. W kilka dni po podaniu cisplatyny w uszkodzonych cewkach, w których wykazano zwiększoną ilość NGAL, można było zaobserwować cechy regeneracji, natomiast cewki, wktórych NGAL byłnieobecny, charakteryzowały się postępującym uszkodzeniem [34]. Wyniki tego badania wskazują na istotną rolę NGAL w mechanizmach związanych z protekcją oraz regeneracją uszkodzonych cewek nerkowych poprzez zwiększenie dokomórkowego transportu jonów żelaza.

\section{NGAL w badaniach klinicznych u pacjentów leczonych cisplatyną}

W przeciwieństwie do pacjentów kardiochirurgicznych wśród pacjentów onkologicznych nie wykazano dotychczas wartości prognostycznej oznaczenia stężenia NGAL w surowicy w wykrywaniu AKI indukowanego cisplatyną [35, 36]. Wśród pacjentów leczonych cisplatyną, zarówno tych, 
Tabela III. Porównanie badań dotyczących oznaczenia NGAL w moczu u pacjentów leczonych cisplatyną

\begin{tabular}{|c|c|c|c|c|c|c|}
\hline $\begin{array}{l}\text { Liczba } \\
\text { badanych }\end{array}$ & Grupa chorych & Cykle & $\begin{array}{c}\text { Odsetek } \\
\text { chorych z AKI }\end{array}$ & Definicja AKI & $\begin{array}{l}\text { Oznaczenia NGAL } \\
\text { w moczu po podaniu } \\
\text { cisplatyny }\end{array}$ & Badanie \\
\hline 33 & $\begin{array}{l}\text { Nowotwory głowy i szyi, } \\
\text { rak przełyku, rak grasicy }\end{array}$ & 1 & $30 \%$ & $\begin{array}{l}\downarrow \text { eGFR } \geq 25 \% \\
\quad \text { w } 4 \text {. dniu }\end{array}$ & $\begin{array}{c}4 h, 8 h, 12 h^{*}, 1 d^{*} \\
2 d^{*}, 3 d^{*}, 4 d\end{array}$ & $\begin{array}{c}\text { Lin HY } 2013 \\
\text { [39] }\end{array}$ \\
\hline 46 & $\begin{array}{l}\text { Nowotwory głowy i szyi, rak pęcherza, } \\
\text { niedrobnokomórkowy rak płuca }\end{array}$ & 1 & $26 \%$ & $\begin{array}{l}\uparrow \text { kreatyniny }>25 \% \\
\text { kiedykolwiek }\end{array}$ & $\begin{array}{l}1 \mathrm{~h}, 4 \mathrm{~h}, 1 \mathrm{~d}^{*}, 2 \mathrm{~d}^{*} \\
3 \mathrm{~d}^{*}, 7 \mathrm{~d}, 15 \mathrm{~d}^{*}\end{array}$ & $\begin{array}{l}\text { Gaspari F } \\
2010[35]\end{array}$ \\
\hline 50 & Nowotwory głowy i szyi & $\begin{array}{l}1 \\
2 \\
3\end{array}$ & $\begin{array}{l}26 \% \\
42 \% \\
29 \%\end{array}$ & $\begin{array}{l}\uparrow \text { kreatyniny } \\
>0,3 \mathrm{mg} / \mathrm{dl} \\
\text { w } 2 . \text { dniu }\end{array}$ & $1 \mathrm{~d}, 2 \mathrm{~d}$ & $\begin{array}{c}\text { Peres LA } 2014 \\
\text { [9] }\end{array}$ \\
\hline 34 & $\begin{array}{l}\text { Nowotwory żołądka, głowy i szyi, płuc, } \\
\text { przełyku, dróg żółciowych }\end{array}$ & $\begin{array}{l}1 \\
3\end{array}$ & nie oceniano & nie oceniano & $\begin{array}{l}\text { NGAL oznaczano } \\
\text { tylko w surowicy** }\end{array}$ & $\begin{array}{c}\text { Kos FT } 2013 \\
\text { [36] }\end{array}$ \\
\hline 24 & $\begin{array}{l}\text { Nowotwory górnego odc. przewodu } \\
\text { pokarmowego, jajnika, opłucnej }\end{array}$ & 1 & $8 \%$ & $\begin{array}{c}\uparrow \text { kreatyniny } \\
>0,3 \mathrm{mg} / \mathrm{dl} \\
\text { lub }>50 \% \text { w } 2 \text {. dniu }\end{array}$ & $6 h, 1 d^{*}, 2 d^{*}, 3 d^{*}$ & $\begin{array}{l}\text { Shahbazi F } \\
2015[40]\end{array}$ \\
\hline $42^{* * *}$ & $\begin{array}{l}\text { Nowotwory płuc, jelita grubego, } \\
\text { układu moczowo-płciowego, żołądka, } \\
\text { trzustki, opłucnej }\end{array}$ & 1 & nie oceniano & nie oceniano & $\begin{array}{c}\text { nie określono } \\
\text { dokładnego przedziału } \\
\text { czasowego }\end{array}$ & $\begin{array}{l}\text { Seker MM } \\
2015[41]\end{array}$ \\
\hline
\end{tabular}

*Znamienny wzrost NGAL w moczu wśród pacjentów z AKI w stosunku do wyjściowego poziomu NGAL

**Bak korelacji pomiędzy poziomem NGAL w surowicy a poziomem kreatyniny w surowicy

***14 pacjentów leczonych cisplatyną, 14 leczonych karboplatyną, 14 leczonych oksaliplatyną

u których nie doszło do rozwoju AKI, jak i tych, u których AKI wystąpiło, stężenie NGAL w surowicy pozostawało na podobnym poziomie przez cały okres obserwacji. Wynika to z faktu, iż w niektórych chorobach nowotworowych dochodzi do wzrostu ekspresji NGAL w komórkach guza [37]. WtkancenowotworowejNGAL, tworzącheterodimerzMMP-9 (metaloproteinazą macierzy zewnątrzkomórkowej typu 9), chroni ten enzym przed autodegradacją [38]. Wytwarzany przez komórki nowotworowe NGAL może maskować wzrost stężenia w surowicy NGAL-u związanego z AKI.

Natomiast NGAL oznaczany w moczu u chorych z AKI indukowanym cisplatyną wykazywał znacznie wcześniejszy wzrost w porównaniu ze wzrostem stężenia kreatyniny w surowicy [35, 39, 40]. U chorych z AKI wzrost stężenia w moczu NGAL obserwowany był już w 12-24 godziny po zakończeniu wlewu cisplatyny (tab. III) i wyprzedzał on wzrost kreatyninemii średnio o 4,5 dnia. Ponadto wzrost stężenia w moczu NGAL był predyktorem przetrwałego uszkodzenie nerek. Wśród pacjentów z AKI, u których w dalszej obserwacji utrzymywało się uszkodzenie nerek, stężenie w moczu NGAL wzrastało wcześniej i szybciej narastało niż u pacjentów, u których funkcja nerek uległa normalizacji [35]. Poprawa funkcji nerek wiązała się ze stopniowym obniżeniem i ostatecznie normalizacją poziomu NGAL w moczu, natomiast w przypadku utrzymywania się upośledzenia ich funkcji poziom NGAL obniżał się wolniej i nie ulegał normalizacji. Analiza krzywej ROC wykazała, że najlepszą wartość wprzewidywaniuwystąpieniaAKImiałyoznaczeniawykonane w 12. i 24. godzinie po zakończeniu wlewu cisplatyny — pole pod krzywą ROC w obu przypadkach wynosiło 0,87 (tab. IV) [39].
Tabela IV. Wartości pola pod krzywą ROC dla oznaczeń NGAL w moczu w diagnostyce ostrego uszkodzenia nerek, w poszczególnych przedziałach czasowych, wśród pacjentów leczonych cisplatyną [39]

\begin{tabular}{lcc}
\hline $\begin{array}{l}\text { Przedziały } \\
\text { czasowe }\end{array}$ & $\begin{array}{c}\text { Pole pod krzywą } \\
\text { ROC }\end{array}$ & $\begin{array}{c}95 \% \text { przedział } \\
\text { ufności }\end{array}$ \\
\hline $0 \mathrm{~h}$ & 0,67 & $0,47-0,87$ \\
$4 \mathrm{~h}$ & 0,68 & $0,47-0,88$ \\
$8 \mathrm{~h}$ & 0,76 & $0,58-0,94$ \\
$12 \mathrm{~h}$ & 0,87 & $0,69-1,00$ \\
$24 \mathrm{~h}$ & 0,87 & $0,70-1,00$ \\
$48 \mathrm{~h}$ & 0,80 & $0,59-1,00$ \\
$72 \mathrm{~h}$ & 0,80 & $0,62-0,98$ \\
$96 \mathrm{~h}$ & 0,81 & $0,64-0,97$ \\
\hline
\end{tabular}

Przytaczane badania były przeprowadzone na grupie pacjentów z wyjściowo prawidłową funkcją nerek, którzy wcześniej nie otrzymywali leczenia nefrotoksycznego, w tym leków onkologicznych, u których monitorowano funkcję nerek jedynie po pierwszorazowym podaniu cisplatyny. Natomiast Peres i wsp. monitorowali stężenie NGAL w moczu po 24 i 48 godzinach w trzech następujących po sobie cyklach obejmujących podania cisplatyny u chorych z nowotworami głowy i szyi [9]. Przed drugim oraz trzecim podaniem wyjściowe wartości NGAL były wyższe niż przed zastosowaniem pierwszego cyklu. Niezależnie od tego kolejne podania cisplatyny powodowały wzrost stężenia w moczu NGAL. Ten wzrost był jednak analizowany dla całej badanej populacji, bez wyodrębnienia podgrupy z AKI. Nie wiemy zatem, jak zachowuje się NGAL w przypadku pacjentów z AKI oraz bez AKI, u których powtórnie, w krótkim odstępie czasu zastoso- 
wano nefrotoksyczną terapię. W 78 dniu obserwacji wśród pacjentów z utrzymującym się zmniejszeniem eGFR $<60 \mathrm{ml} /$ /min/1,73 m² średni poziom w moczu NGAL był wyższy niż w przypadku pacjentów z prawidłowymi wartościami eGFR. Obserwacja ta sugeruje, że NGAL może być przydatny nie tylko we wczesnym rozpoznawaniu $\mathrm{AKl}$, ale również może służyć do przewlekłego monitorowania funkcji nerek.

Ponadto osobną kwestią pozostaje możliwość wykorzystanie NGAL w celu monitorowania funkcji nerek w przypadku stosowania innych, mniej nefrotoksycznych pochodnych platyny. W badaniu Sekera i wsp. oznaczano poziom NGAL w moczu pacjentów po podaniu cisplatyny, karboplatyny oraz oksaliplatyny, stwierdzając jego wzrost odpowiednio u 71,4\%, 78,5\% oraz 57,1\% pacjentów [41]. Jednak ze względu na małą wielkość grupy badanej (14 pacjentów w każdej podgrupie) oraz na brak monitorowania funkcji nerek w kolejnych dniach terapii bardziej szczegółowa interpretacja wyników nie jest możliwa.

\section{Podsumowanie}

Obecnie stosowane kryteria AKI opierają się na zmianach poziomu kreatyniny, GFR lub diurezy. W przypadku pacjentów leczonych cisplatyną, ze względu na nieoliguryczne postaci AKI, w praktyce wykonuje się jedynie seryjne oznaczenia stężenia kreatyniny w surowicy, a na ich podstawie wylicza zmiany wartość eGFR. Stosowanie tego markeru wiąże się jednak ze znacznym opóźnieniem w rozpoznawaniu AKI, jak również nierozpoznawaniem mniej nasilonych epizodów uszkodzenia nerek.

Nowym, potencjalnym markerem uszkodzenia cewek nerkowych, adekwatnym dla profilu nefrotoksyczności cisplatyny, jest NGAL, oznaczany w moczu. Wzrost stężenia NGAL w moczu jest wykrywany po 12-24 godzinach, zanim dojdzie do wzrostu kreatyniny i spadku filtracji kłębuszkowej, pozwalając na rozpoznanie postaci subklinicznych AKI. Ograniczeniem stosowania tego markera jest obecnie brak określonego stężenia w moczu NGAL pozwalającego na rozpoznanie nefrotoksyczności cisplatyny (subklinicznego AKI).

Wykrycie subklinicznego uszkodzenia nerek w przypadku terapii cisplatyną daje możliwość zastosowania intensywnych metod profilaktyki AKI przed kolejnym podaniem cisplatyny lub rozważenie zastosowania innego, mniej nefrotoksycznego schematu leczenia, jeśli jest to możliwe.

\section{Konflikt interesów: nie zgłoszono}

\section{Lek. Dawid Szumilas}

Katedra i Klinika Chorób Wewnętrznych i Chemioterapii Onkologicznej Wydział Lekarski

Śląski Uniwersytet Medyczny w Katowicach

ul. Reymonta 8, 40-027 Katowice

e-mail:dawid_szumilas@wp.eu

Otrzymano: 22 września 2015 r.

Przyjęto do druku: 4 stycznia $2016 \mathrm{r}$.

\section{Piśmiennictwo}

1. Hartmann JT, Lipp HP. Toxicity of platinum compounds. Expert Opin Pharmacother 2003; 4: 889-901.

2. Schaeppi U, Heyman IA, Fleischman RW i wsp. cis-Dichlorodiammineplatinum(II) (NSC-119 875): preclinical toxicologic evaluation of intravenous injection in dogs, monkeys and mice. Toxicol Appl Pharmacol 1973; 25: 230-241.

3. Gonzales-Vitale JC, Hayes DM, Cvitkovic E i wsp. The renal pathology in clinical trials of cis-platinum (II) diamminedichloride. Cancer 1977; 39: 1362-1371.

4. Santoso JT, Lucci JA 3rd, Coleman RL i wsp. Saline, mannitol, and furosemide hydration in acute cisplatin nephrotoxicity: a randomized trial. Cancer Chemother Pharmacol 2003; 52: 13-18.

5. Prasaja Y, Sutandyo N, Andrajati R. Incidence of cisplatin-induced nephrotoxicity and associated factors among cancer patients in Indonesia. Asian Pac J Cancer Prev 2015; 16: 1117-1122.

6. Hartmann JT, Kollmannsberger C, Kanz L i wsp. Platinum organ toxicity and possible prevention in patients with testicular cancer. Int J Cancer 1999; 83: 866-869.

7. Libório AB, Abreu KL, Silva GB Jr i wsp. Predicting hospital mortality in critically ill cancer patients according to acute kidney injury severity. Oncology 2011; 80: 160-166.

8. Rosa J, Sydor A, Sułowicz W. Outcome of patients with acute kidney injury in the course of neoplastic diseases. Przegl Lek 2014; 71: 72-77.

9. Peres LA, da Cunha AD Jr, Assumpção RA i wsp. Evaluation of the cisplatin nephrotoxicity using the urinary neutrophil gelatinase-associated lipocalin (NGAL) in patients with head and neck cancer. J Bras Nefrol 2014; 36: 280-288.

10. Bellomo R, Ronco C, Kellum JA i wsp. Acute renal failure-definition, outcome measures, animal models, fluid therapy and information technology needs: the Second International Consensus Conference of the Acute Dialysis Quality Initiative (ADQI) Group. Critical Care 2004; 8: R204-212.

11. Mehta RL, Kellum JA, Shah SV i wsp. Acute Kidney Injury Network: report of an initiative to improve outcomes in acute kidney injury. Crit Care 2007; 11: R31.

12. Levey AS, Greene T, Kusek JW i wsp. A simplified equation to predict glomerular filtration rate from serum creatinine (abstract) J Am Soc Nephrol 2000; 11: 155A

13. Shemesh $\mathrm{O}$, Golbetz $\mathrm{H}$, Kriss JP i wsp. Limitations of creatinine as a filtration marker in glomerulopathic patients. Kidney Int 1985; 28: 830-838.

14. Dobyan DC, Levi J, Jacobs C i wsp. Mechanism of cis-platinum nephrotoxicity: II. Morphologic observations. J Pharmacol Exp Ther 1980; 213: 551-556.

15. Xu Y, Xie Y, Shao X i wsp. L-FABP: A novel biomarker of kidney disease. Clin Chim Acta 2015; 445: 85-90.

16. Lin X, Yuan J, Zhao Y i wsp. Urine interleukin-18 in prediction of acute kidney injury: a systemic review and meta-analysis. J Nephrol 2015; 28: 7-16.

17. Friedl A, Stoesz SP, Buckley P i wsp. Neutrophil gelatinase-associated lipocalin in normal and neoplastic human tissues. Cell type-specific pattern of expression. Histochem J 1999; 31: 433-441.

18. Schmidt-Ott KM, Mori K, Li JY i wsp. Dual action of neutrophil gelatinase-associated lipocalin. J Am Soc Nephrol 2007; 18: 407-413.

19. Mori K, Lee HT, Rapoport D i wsp. Endocytic delivery of lipocalin-siderophore-iron complex rescues the kidney from ischemia-reperfusion injury. J Clin Invest 2005; 115: 610-621.

20. Cowland JB, Borregaard N. Molecular characterization and pattern of tissue expression of the gene for neutrophil gelatinase-associated lipocalin from humans. Genomics 1997; 45: 17-23.

21. Kjeldsen $L$, Johnsen $A H$, Sengeløv $H$ i wsp. Isolation and primary structure of NGAL, a novel protein associated with human neutrophil gelatinase. J Biol Chem 1993; 268: 10425-10432.

22. Kanda J, Mori K, Kawabata H i wsp. An AKI biomarker lipocalin 2 in the blood derives from the kidney in renal injury but from neutrophils in normal and infected conditions. Clin Exp Nephrol 2015; 19: 99-106.

23. Axelsson $L$, Bergenfeldt M, Ohlsson K. Studies of the release and turnover of a human neutrophil lipocalin. Scand J Clin Lab Invest 1995; 55: 577-588.

24. Mishra J, Ma Q, Prada A i wsp. Identification of neutrophil gelatinase-associated lipocalin as a novel early urinary biomarker for ischemic renal injury. J Am Soc Nephrol 2003; 14: 2534-2543.

25. Schmidt-Ott KM, Mori K, Kalandadze A i wsp. Neutrophil gelatinase-associated lipocalin-mediated iron traffic in kidney epithelia. Curr Opin Nephrol Hypertens 2006; 15: 442-449. 
26. Grigoryev DN, Liu M, Hassoun HT i wsp. The local and systemic inflammatory transcriptome after acute kidney injury. J Am Soc Nephrol 2008; 19: 547-558.

27. Bao G, Clifton M, Hoette TM i wsp. Iron traffics in circulation bound to a siderocalin (Ngal)-catechol complex. Nat Chem Biol 2010; 6: 602-609.

28. Mishra J, Dent C, Tarabishi R i wsp. Neutrophil gelatinase-associated lipocalin (NGAL) as a biomarker for acute renal injury after cardiac surgery. Lancet 2005; 365: 1231-1238.

29. Tuladhar SM, Püntmann VO, Soni M i wsp. Rapid detection of acute kidney injury by plasma and urinary neutrophil gelatinase-associated lipocalin after cardiopulmonary bypass. J Cardiovasc Pharmacol 2009; 53: $261-266$.

30. Haase M, Devarajan P, Haase-Fielitz A i wsp. The outcome of neutrophil gelatinase-associated lipocalin-positive subclinical acute kidney injury: a multicenter pooled analysis of prospective studies. J Am Coll Cardiol 2011; 57: 1752-1761.

31. Mishra J, Mori K, Ma Q i wsp. Neutrophil gelatinase-associated lipocalin: a novel early urinary biomarker for cisplatin nephrotoxicity. Am J Nephrol 2004; 24: 307-315.

32. Sinha V, Vence LM, Salahudeen AK. Urinary tubular protein-based biomarkers in the rodent model of cisplatin nephrotoxicity: a comparative analysis of serum creatinine, renal histology, and urinary KIM-1, NGAL, and NAG in the initiation, maintenance, and recovery phases of acute kidney injury. J Investig Med 2013; 61: 564-568.

33. Vinken P, Starckx S, Barale-Thomas E i wsp. Tissue Kim-1 and urinary clusterin as early indicators of cisplatin-induced acute kidney injury in rats. Toxicol Pathol 2012; 40: 1049-1062.

34. Kashiwagi E, Tonomura $\mathrm{Y}$, Kondo $\mathrm{C}$ i wsp. Involvement of neutrophil gelatinase-associated lipocalin and osteopontin in renal tubular re- generation and interstitial fibrosis after cisplatin-induced renal failure. Exp Toxicol Pathol 2014; 66: 301-311.

35. Gaspari F, Cravedi P, Mandalà M i wsp. Predicting cisplatin-induced acute kidney injury by urinary neutrophil gelatinase-associated lipocalin excretion: a pilot prospective case-control study. Nephron Clin Pract 2010; 115: c154-160.

36. Kos FT, Sendur MA, Aksoy S i wsp. Evaluation of renal function using the level of neutrophil gelatinase-associated lipocalin is not predictive of nephrotoxicity associated with cisplatin-based chemotherapy. Asian Pac J Cancer Prev 2013; 14: 1111-1114.

37. Candido S, Maestro R, Polesel J i wsp. Roles of neutrophil gelatinase-associated lipocalin (NGAL) in human cancer. Oncotarget 2014; 5: 1576-1594.

38. Yan L, Borregaard N, Kjeldsen Li wsp. The high molecular weight urinary matrix metalloproteinase (MMP) activity is a complex of gelatinase B/MMP-9 and neutrophil gelatinase-associated lipocalin (NGAL). Modulation of MMP-9 activity by NGAL. J Biol Chem 2001; 276: 37258-37265.

39. Lin HY, Lee SC, Lin SF i wsp. Urinary neutrophil gelatinase-associated lipocalin levels predict cisplatin-induced acute kidney injury better than albuminuria or urinary cystatin C levels. Kaohsiung J Med Sci 2013; 29: 304-311.

40. Shahbazi F, Sadighi S, Dashti-Khavidaki S i wsp. Urine ratio of neutrophil gelatinase-associated lipocalin to creatinine as a marker for early detection of cisplatin-associated nephrotoxicity. Iran J Kidney Dis 2015; 9: 306-310.

41. Seker MM, Deveci K, Seker A i wsp. Predictive role of neutrophil gelatinase-associated lipocalin in early diagnosis of platin-induced renal injury. Asian Pac J Cancer Prev 2015; 16: 407-410. 